\title{
MODELLING THE EFFECTS OF GLOBAL TEMPERATURE INCREASE ON THE GROWTH OF SALT MARSH PLANTS
}

\author{
T. COUTO ${ }^{1}$ * - I. MARTINS ${ }^{2}$ - B. DUARTE ${ }^{3}$ - I. CAÇADOR ${ }^{3}$ - J. C. MARQUES ${ }^{1}$ \\ ${ }^{1}$ IMAR - Institute of Marine Research, Department of Life Sciences, Faculty of Sciences and \\ Technology, University of Coimbra, 3004-517 Coimbra, Portugal \\ ${ }^{2}$ School of Ocean Sciences - Bangor University, Menai Bridge, Anglesey, LL59 5AB, UK \\ ${ }^{3}$ Centre of Oceanography, Faculty of Sciences, University of Lisbon, Campo Grande, 1749-016 \\ Lisbon, Portugal \\ * Corresponding author \\ E-mail address:thiagoc@uc.pt \\ (phone: + 351-239-836-386; fax: +351-266-760-912) \\ (Received $28^{\text {th }}$ March 2014; accepted $22^{\text {nd }}$ July 2014)
}

\begin{abstract}
Gradual increases in temperature and atmospheric $\mathrm{CO}_{2}$ concentrations have resulted from the increased human use of fossil fuels since the beginning of industrial activity. In coastal wetland ecosystems, salt marshes constitute important habitats because they play important ecological roles, acting as carbon sinks by capturing atmospheric $\mathrm{CO}_{2}$ and storing it in living plant tissue. Ecological models are important tools for understanding the results of anthropogenic impacts on a global scale. Global warming poses threats to salt marshes through different effects, e.g., increases in sea level. The objectives of this study were i) to assess how temperature increases will influence the growth of salt marsh plants, ii) to infer the carbon budget of salt marshes under temperature increase scenarios and iii) to predict how salt marsh plants will keep pace with increases in sea level. These goals were achieved by developing growth models of three different plants (Spartina maritima, Scirpus maritimus and Zostera noltei) found in the Mondego estuary. Models were developed for $\mathrm{C}_{3}$ and $\mathrm{C}_{4}$ plant species. The results suggest that a temperature increase enhances the aboveground biomass of salt marsh plants. According to the predictions of the models, the sedimentation rate of S. maritima and Z. noltei can keep pace with increases in sea level, but this is apparently not the case for $S$. maritimus. If $S$. maritimus disappears from the Mondego estuary, the carbon sequestration ability of the system should decrease due to the loss of active plant tissue. This conclusion is based on the fact that $S$. maritimus accumulated more than $80 \%$ of the total carbon sequestered in the tissues by the three studied species.
\end{abstract}

Keywords: plant growth model, sea level increase, sedimentation, salt marsh, estuaries

\section{Introduction}

Because of increasing human fossil fuel use since the beginning of intensive industrial activity (Houghton, 1999), the world has experienced an increase in atmospheric $\mathrm{CO}_{2}$. It is widely believed that anthropogenic additions of $\mathrm{CO}_{2}$ to the atmosphere are contributing to increase surface temperatures worldwide, a phenomenon known as the "greenhouse effect" (Bluemle et al., 1999). IPCC (2007) reports show that the global temperature increased approximately $0.3{ }^{\circ} \mathrm{C}$ per decade from 1979 to 2005. Coastal wetlands such as salt marshes are excellent carbon sinks, as they withdraw $\mathrm{CO}_{2}$ from the atmosphere and store it in living plant tissue (Williams, 1999). Salt marshes reduce the rates of greenhouse gas emissions (Magenheimer et al., 1996) and have a carbon sequestration capacity per unit area approximately one order of magnitude higher than other wetland systems (Bridgham et al., 2006), with the potential to sequester carbon continuously over thousands of years (Brevik et al, 2004). In 
addition to their carbon storage capacity, salt marshes are key areas for estuarine systems because of their role in primary production and nutrient regeneration (Caçador et al., 2009). They represent one of the most productive ecosystems on the planet (Lefeuvre et al., 2003). However, global warming can threaten salt marsh areas through, e.g., increases in sea level. Salt marsh ecosystems play a vital role in the dissipation of wave energy, accretion of sediment and filtration of nutrients and as habitats supporting commercially important fisheries (Mudd et al. 2009). These ecosystems are vulnerable to changes in sea level (Cundy \& Croudace, 1996, Rybczyk \& Cahoon, 2002), and sea level increases have become a severe threat to coastal zones and estuaries at low elevations (Vandenbruwaene et al. 2011). It is recognised that many marshes are able to keep pace with increases in sea level (Friedrichs and Perry, 2001); the response of coastal marshes to relative increases in sea level depends upon their ability to maintain their relative elevation through sedimentation (Reed, 1990). IPCC (2007) reports show that the most pessimistic prediction for sea level change is an increase of approximately $0.97 \mathrm{~cm}$ per year, which will endanger certain areas around the world that are influenced by the tides, including, in particular, the Mondego salt marsh. Ecological models have been used to clarify the effects of anthropogenic impacts on a global scale by integrating processes related to the biota of the ecosystem in its conceptual structure (Fragoso Jr., et al. 2009). Accordingly, an ecological model focuses on the objects of interest for a considered and well-defined problem. There can be many different ecological models of the same ecosystem, as the model version is selected according to the goals of modelling (Jørgensen \& Fath, 2011). Because Spartina maritima, Scirpus maritimus and Zostera noltei together occupy approximately $50 \%$ of the salt marsh vegetation of the Mondego estuary (Neto, unpublished data), these species were selected as the focus of the present study. Our goal was to examine the influence of temperature increase on the carbon accumulation of the salt marsh area of the Mondego estuary. Specifically, our objectives were to investigate how temperature increase influences the growth of salt marsh plants (Spartina maritima, Scirpus maritimus and Zostera noltei) and their carbon storage capacity. Furthermore, we attempted to estimate whether the sedimentation rate of the three salt marsh plants can keep pace with the increase in sea level.

\section{Materials and methods}

\section{Study site}

The Mondego estuary (Fig. 1) is located on the Portuguese Atlantic coast $\left(40^{\circ} 08 \mathrm{~N}\right.$, $8^{\circ} 50 \mathrm{~W}$ ) (Marques and Nogueira, 1991). The estuary is approximately $8.6 \mathrm{~km}^{2}$ in area, and its upstream limit extends up to $21 \mathrm{~km}$ from the mouth of the estuary (Teixeira et $a l ., 2008$ ). The final portion of the estuary (approximately $7 \mathrm{~km}$ ) is divided into two arms (north and south) by Murraceira Island (Marques et al., 2003). The sample sites for this study (Fig. 1) were located in the south arm of the estuary. The south arm is shallower than the north arm (2-4 m during high tide) and is characterised by large areas of intertidal mudflats (almost $75 \%$ of the area) (Neto et al., 2008). The sediments of the south arm contain a high percentage of silt and clay, and the area is considered to be a rich estuarine habitat in terms of productivity and biodiversity (Marques et al., 1993). 


\section{Field data sampling and laboratory procedures}

Field data sampling was conducted seven times, once in each season, between 2010 (spring, summer and autumn) and 2011 (winter, spring, summer and autumn). For the aboveground biomass, three replicates ( $\operatorname{size}=0.3 \times 0.3 \mathrm{~m}$ squares) of each salt marsh plant species were randomly selected in each area and clipped (Caçador et al., 2004). In the laboratory, all samples were washed with ultrapure water $(18.2 \mathrm{M} \Omega \mathrm{cm})$. The aboveground tissues were then dried at $60{ }^{\circ} \mathrm{C}$ until a constant weight was achieved, and the dried tissues were pulverised with a grinding ball mill (Glen Creston MM2000) (Gross et al., 1991). Total carbon content was determined using a CHNS/O analyser (Fisons Instruments Model EA 1108). The carbon pool (grams) for each species and for each season analysed was calculated by multiplying the results from the CHNS/O analyser, expressed as a percentage (\%), by the biomass according to equation 1 .

(Eq.1)

Sedimentation rates were measured using lengths of wood with millimetre marks, which were buried up to the zero mark level in the area occupied by each species. This procedure was performed in February 2011 in the sampling areas corresponding to the three salt marsh plants. One year later (February 2012), the wooden markers were checked to measure the level corresponding to sediment accumulation in each of the three sampling areas.

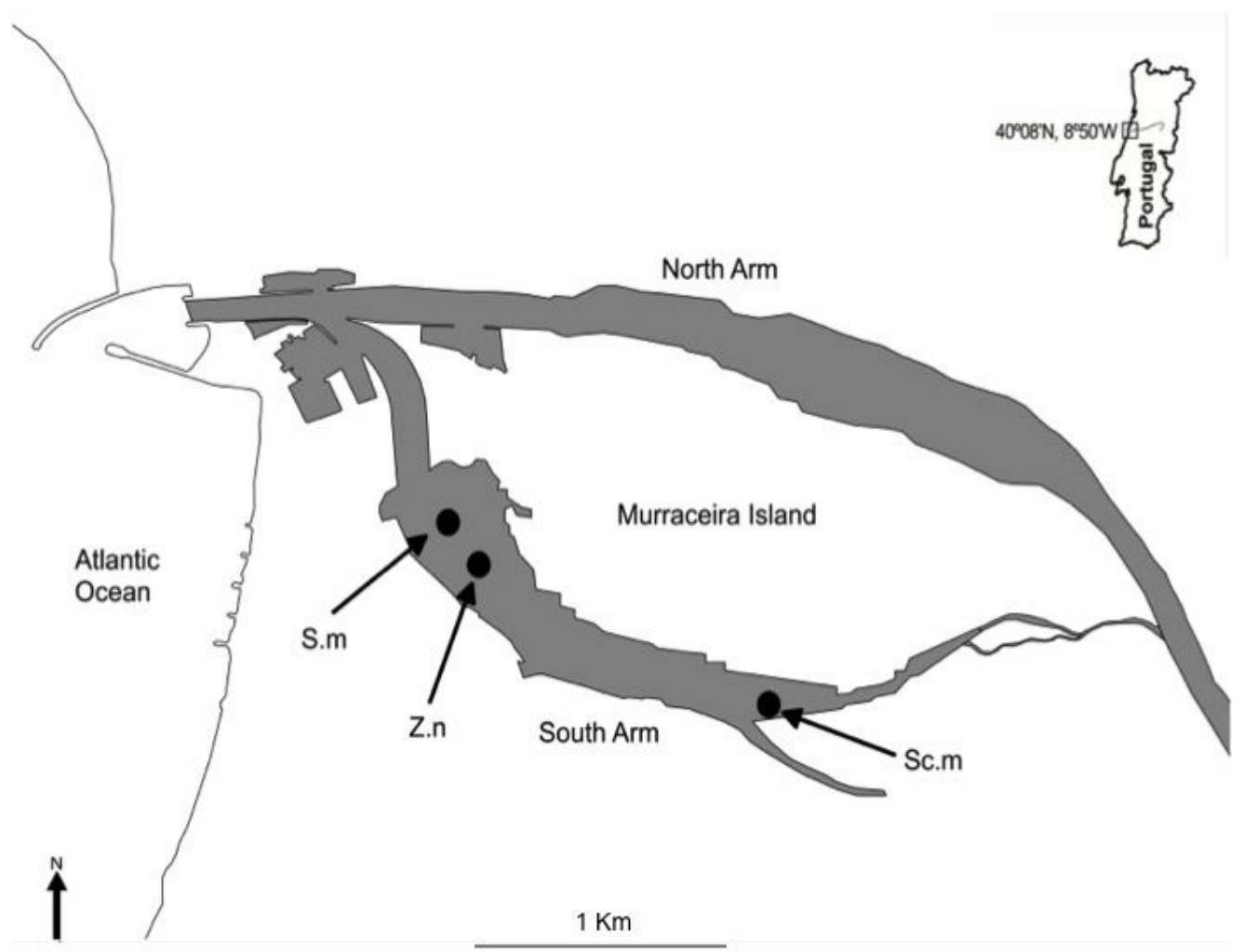

Figure 1. Sampling locations in the south arm of the Mondego estuary. S.m (Spartina maritima), Z.n (Zostera noltei) and Sc.m (Scirpus maritimus). 


\section{Model}

To simulate the growth of a primary producer, a model must include the principal physiological processes, such as photosynthesis, respiration and exudation (Duarte, 2011). The present study follows the work of Simas et al. (2001), where fluxes are expressed as $\mathrm{gC}$ dry weight $\mathrm{m}^{-2}$; the key equation is

$$
\frac{d B}{d t}=\mu-R-L_{m}-E
$$

where $B$ is plant biomass, $\mu$ is gross productivity, $R$ is respiration, $L_{m}$ is leaf mortality and $E$ is exudation. Gross production $(\mu)$ is represented by equation 3:

$$
\mu=P_{\max } \times f(T) \times f(I) \times f(N)
$$

where $P_{\max }$ is the plant's maximum production, $f(T)$ is the air temperature function, $f(I)$ is the light function and $f(N)$ is the nutrient function.

$P_{\max }$ values for each studied plant species are shown in table I. The air temperature function $f(T)$ is described in equation 4 (Bach, 1993):

$$
f(T)=\gamma_{1}^{\left(T-T_{\mathrm{ppp}}\right)}
$$

where $\gamma_{1}$ is the temperature coefficient for growth, $T$ is the daily air temperature and $T_{\text {opt }}$ is the optimum temperature for growth.

The daily temperature variation $(T)$ throughout the year was obtained from a modified sine equation (Anastácio et al., 1995) (Equation 5):

$$
T=\frac{\left(T_{\max }+T_{\min }\right)}{2}+\frac{\left(T_{\max }-T_{\min }\right)}{2} \times \operatorname{SNN}\left(\left(\frac{t_{\operatorname{man}}}{365}-0.23\right) \times 2 \times \pi\right)
$$

where $T_{\max }$ is the maximum air temperature $\left(39.2^{\circ} \mathrm{C}\right)$ and $T_{\min }$ the minimum air temperature $\left(-2.4^{\circ} \mathrm{C}\right)$ during the study period. The maximum and minimum temperature values were obtained from the Portuguese Meteorology Institute (IPMA).

The light function was defined as a Michaelis-Menten equation:

$$
f(I)=\frac{I}{b_{k}+I}
$$

where $I$ is the light intensity and $I_{k}$ is the half-saturation constant. Daily values of light intensity at $40^{\circ}$ latitude were obtained from the Portuguese Environment Agency (APA), and half-saturation constants for the three plant species were obtained from the literature (Morris, 1982).

The regulation of growth by nitrogen $(f(N))$ is expressed in Equation 7: 


$$
f(N)=\frac{N}{(N+\eta)}
$$

where $N$ is the concentration (\%) of nitrogen in the leaves and $\eta$ is the half-saturation constant $(\%)$ for nitrogen.

Leaf mortality $\left(L_{m}\right)$ is dependent on temperature (equation 8):

$$
L_{m}=L_{\max }\left(\gamma_{2}^{T-T_{p p t}}\right) H
$$

$\boldsymbol{L}_{m}=L_{\max }\left(\gamma_{2}^{T-T_{a p t}}\right)$ where $L_{\max }$ is the maximum leaf mortality rate, $\gamma_{2}$ is the temperature coefficient for leaf mortality and $H$ is the loss of aboveground biomass due to wave motion, calculated using equation 9:

$$
H=1+W_{1} e^{-W_{2} h}
$$

where $W_{1}$ and $W_{2}$ are constants and $h$ is the tidal height.

Exudation $(E)$ (equation 10) is the release of dissolved organic carbon and can be calculated as a fraction of gross production (Baretta-Bekker et al. 1997):

$$
E=\mu[\alpha+(1-\alpha)(1-f(N))]
$$

where $\alpha$ is the fraction of gross production that is excreted under nutrient stress conditions (Simas et al. 2001).

The respiration rate $(R)$ is dependent on the temperature and on the assimilated biomass (Baretta-Bekker et al., 1997) and can be calculated as in equation 11:

$$
R=r^{b a s} Q_{10}^{T /\left(T_{p p t}-1\right)}+q^{r \theta s}(\mu-E)
$$

where $r^{b a s}$ is the basal respiration, $Q_{10}$ is the $\mathrm{Q}_{10}$ value and $q^{\text {res }}$ is the fraction of production lost by respiration.

\section{Model calibration and scenario simulations}

The model was built using STELLA software (version 9.0) (Isee systems). As in Simas et al. 2001, the model was calibrated independently for $\mathrm{C}_{3}$ (Scirpus maritimus) and $\mathrm{C}_{4}$ (Spartina maritima, Zostera noltei) species. The model was run for a two-year period corresponding to the sampling period, and the predictions were compared with the observations. The parameter values used in the model are shown in table I.

To test the influence of temperature on the biomass production of the three plant species in the model, the temperature was increased by $1.5^{\circ} \mathrm{C}$. 


\title{
Sensitivity analyses
}

A sensitivity analysis was performed on selected key parameters to assess the variation in the biomass of the three salt marsh plants when the parameters were changed. The parameters were changed in $\pm 10 \%$ steps (Jørgensen and Fath, 2011).

\section{Sea level increase}

To study the sedimentation rate associated with the area occupied by each studied salt marsh species relative to sea level increase, the bathymetry of the area occupied by each plant was considered along with the average height of each plant species, namely, $1.20 \mathrm{~m}$ for $S$. maritimus, $0.7 \mathrm{~m}$ for $S$. maritima and $0.3 \mathrm{~m}$ for $Z$. noltei. A sea level increase of $0.97 \mathrm{~cm}$ per year was simulated and compared with the sedimentation rate of each species. Bathymetry data for the Mondego estuary were extracted from Kenov et al. (2012), and the average maximum and minimum tidal heights were obtained from the Portuguese Hydrographic Institute (IH). A constant sedimentation rate $\left(2.7 \mathrm{~cm} \mathrm{y}^{-1}\right.$ for Z. noltei, $1 \mathrm{~cm} \mathrm{y}^{-1}$ for $S$. maritima and $0.2 \mathrm{~cm} \mathrm{y}^{-1}$ for $S$. maritimus) and constant rate of sea level increase $\left(0.97 \mathrm{~cm} \mathrm{y}^{-1}\right)$ were assumed.

\section{Statistical analysis}

To compare the biomass results between the model simulation using the actual temperature and the simulation with the $1.5{ }^{\circ} \mathrm{C}$ increase in temperature, a one-way ANOSIM test using Primer software, version 6 (Clarke, 1993) was performed. The model predictions and observations were compared using a regression analysis.

Table 1. Parameters values used in the model. A major part of the values were gathered from the works of Simas et al. 2001 and 2007.

\begin{tabular}{|c|c|c|c|c|c|c|}
\hline Code & Description & Units & $\begin{array}{l}\text { Scipus } \\
\text { maritimus }\end{array}$ & $\begin{array}{l}\text { Spartina } \\
\text { maritima }\end{array}$ & Zostera noltei & References \\
\hline$P_{\max }$ & Maximumproductionrate & $\mathrm{gC} \mathrm{dw} \mathrm{m} \mathrm{m}^{-2} \mathrm{~d}^{-1}$ & 1.23 & 2.4 & 0.27 & $\begin{array}{l}\text { Curtis et al., 1989a; Curtis et al., 1989b; } \\
\text { Sousa et al., 2010; Bach, 1993 }\end{array}$ \\
\hline$\eta$ & Temperature coefficient for growth & $\cdot$ & 1.1 & 1.08 & 1.08 & Bach 1993 \\
\hline$T_{o p t}$ & Optimum temperature for growth & ${ }^{\circ} \mathrm{C}$ & 21 & 25 & 25 & Giurgevich and Dunn 1981 \\
\hline$I_{k}$ & Light half saturation constant & $\mathrm{Wm}^{-2}$ & 177 & 250 & 250 & Momis 1982 \\
\hline$\eta$ & Nitrogen half saturation constant & $\%$ & 0.36 & 0.36 & 0.36 & Momis 1982 \\
\hline$L_{\max }$ & Maximumleaf mortality rate & $g C \mathrm{dw} \mathrm{d}^{-1}$ & 0.812 & 0.5774 & 0.0641 & $*$ \\
\hline$\eta$ & Temperature coefficient for leaf mortality & $\cdot$ & 1.07 & 1.07 & 1.07 & Bach 1993 \\
\hline$W_{1}$ & Coefficient for $H($ Eq. 8) & $\cdot$ & 30 & 30 & 30 & Bach 1993 \\
\hline$W_{2}$ & Coefficient for $H$ (Eq. 8) & $\mathrm{m}^{-1}$ & 1.5 & 1.5 & 1.5 & Bach 1993 \\
\hline$\alpha$ & Exudation undernutrient stress & - & 0.2 & 0.2 & 0.2 & Bach 1993 \\
\hline$r^{\text {bas }}$ & Basalrespiration & $\mathrm{d}^{-1}$ & $8.4 \times 10^{-4}$ & $5.52 \times 10^{-4}$ & $5.52 \times 10^{-4}$ & Simas et al. 2001 \\
\hline Q10 & Q10value & $\cdot$ & 2 & 2 & 2 & Baretta-Bekker et al. 1997 \\
\hline$q^{r e s}$ & Production respired fraction & - & 0.1 & 0.1 & 0.1 & Baretta-Bekker et al. 1997 \\
\hline
\end{tabular}

- Values estimated at calibration.

\section{Results and discussion}

\section{Model predictions and observed biomass}

\author{
APPLIED ECOLOGY AND ENVIRONMENT AL RESEARCH 12(3): 753-764. \\ http://www.aloki.hu • ISSN 15891623 (Print) • ISSN 17850037 (Online) \\ DOI: 10.15666/aeer/1203 753764 \\ (c) 2014, ALÖKI Kft., Budapest, Hungary
}


The model results followed the same pattern as the observed values (Fig. 2), with plant aboveground biomass values usually higher in the warm seasons than in the cold seasons, as also shown by several other studies (Caçador et al., 2004; Couto et al., 2013; Duarte et al. 2012; Lillebø et al., 2003). Because the observed values in the spring of 2010 for S. maritimus and Z. noltei were unusually high, they were excluded from the linear regression calculations. The regression (Fig. 2) demonstrated that the observed and model results showed similar variation, although the data for S. maritima showed the best fit, followed by $S$. maritimus and $Z$. noltei. The sensitivity analysis (table II) showed that the parameters with the greatest influence on the biomass values of the three plant species were the maximum temperature $\left(T_{\max }\right)$ and the maximum leaf mortality rate $\left(L_{\max }\right)$. A change of $\pm 10 \%$ in these parameters could increase or decrease the average biomass by more than $50 \%$.
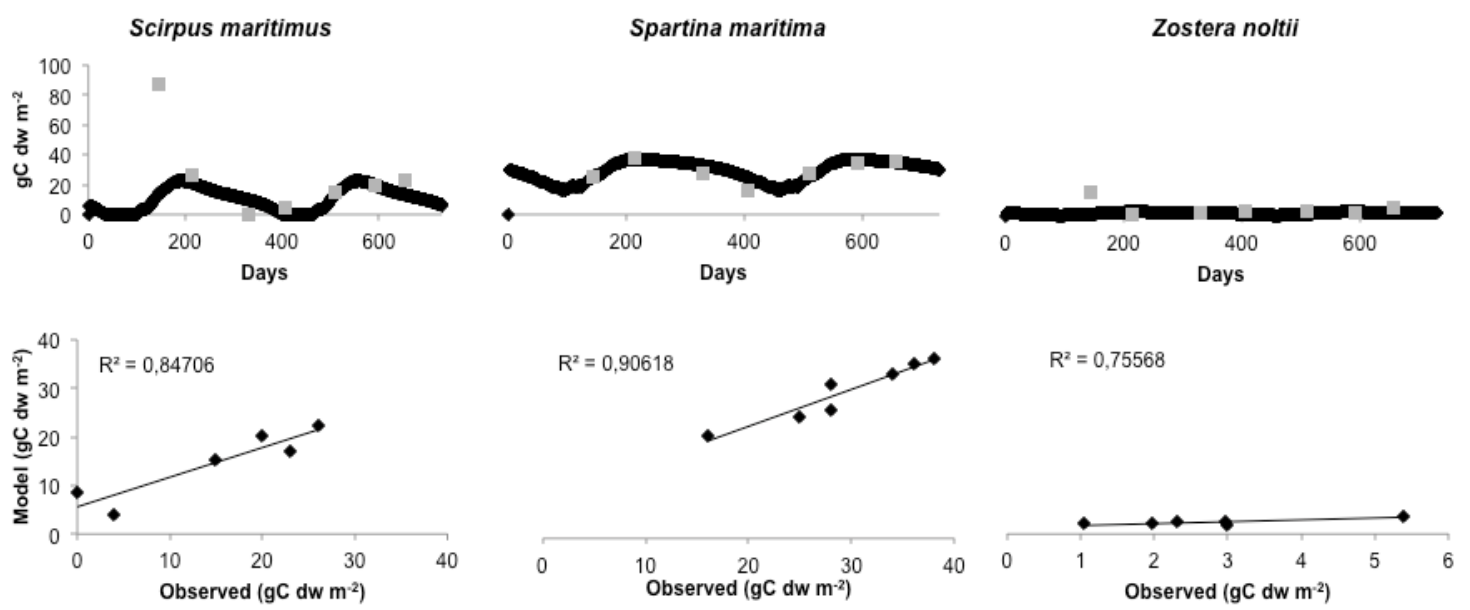

Figure 2. Observed (grey squares) and model (black line) values during 730 days and linear regression comparing both results for each species.

\section{Temperature increase}

IPCC reports (IPCC, 2007) state that the global temperature has increased approximately $0.3{ }^{\circ} \mathrm{C}$ every 10 years since 1979. Fig. 3 shows the results of a comparison between the model results with the actual temperature and the model results assuming an increase of $1.5{ }^{\circ} \mathrm{C}$. The results indicate that in such a scenario (a temperature increase of $1.5^{\circ} \mathrm{C}$ ), S. maritimus and Z. noltei would show an increase of approximately $30 \%$ in maximum biomass compared with the simulation using the actual temperature, whereas S. maritima would show an increase of $10 \%$ in maximum biomass.

The increase in temperature apparently has a positive effect in the model, as the increased plant biomass promoted by the increased temperature will absorb more carbon from the atmosphere. However, temperature increase will certainly affect the system in other ways. For example, it will cause sea level to increase due to oceanic thermal expansion, and also due to the melting of Arctic and Antarctic ice (Titus et al., 1991). This process could be detrimental to salt marshes because the sea level increase would place increased stress on certain marshes; these marshes might ultimately be submerged (Silliman et al., 2009). 
Table 2.. Sensitivity analyses of the average biomass of the total study period in relation to key parameters. The results are in percentage of the standard model. Sc.m: S. maritimus; S.m: S. maritima; Z.n: Z. noltei.

\begin{tabular}{ccccccc}
\hline & \multicolumn{2}{c}{ Sc.m } & \multicolumn{2}{c}{ S.m } & \multicolumn{3}{c}{ Z.n } \\
\hline Parameters & $10 \%$ & $-10 \%$ & $10 \%$ & $-10 \%$ & $10 \%$ & $-10 \%$ \\
\hline$I_{k}$ & -40 & 52 & -37 & 40 & -49 & 76 \\
\hline$T_{\max }$ & 322 & -83 & 43 & -30 & 79 & -44 \\
\hline$T_{\min }$ & 0,2 & $-0,1$ & -4 & 1 & -1 & 0 \\
\hline$N$ & 41 & -41 & 23 & -30 & 44 & -40 \\
\hline$\eta$ & -38 & 46 & -27 & 27 & -37 & 49 \\
\hline$r^{\text {bas }}$ & $-0,3$ & $-0,3$ & -4 & -4 & -3 & 2 \\
\hline$Q_{10}$ & $-0,4$ & $-0,3$ & -4 & -4 & -3 & 2 \\
\hline$q^{\text {res }}$ & -14 & 14 & -10 & 6 & -17 & 16 \\
\hline$L_{\text {max }}$ & -72 & 187 & -70 & 80 & -76 & 145 \\
\hline
\end{tabular}
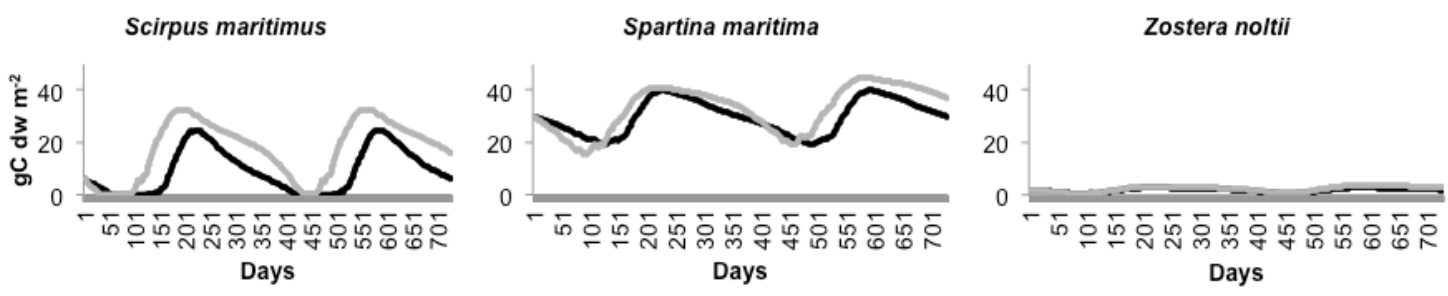

Figure 3. Model results for the actual temperature (black line) and for the $1.5{ }^{\circ} \mathrm{C}$ increase in the temperature (grey line) during 730 days.

\section{Sea level increase and sedimentation}

Kenov et al. (2012) have shown that the bathymetry data of the sand banks for the three studied species in the Mondego estuary correspond to an elevation of approximately $2 \mathrm{~m}$ above sea level. The average heights of the studied species are 1.20 $\mathrm{m}$ for $S$. maritimus, $0.7 \mathrm{~m}$ for $S$. maritima and $0.3 \mathrm{~m}$ for $Z$. noltei. The sum of the heights of the banks and the average height of each species is approximately $3.2 \mathrm{~m}$ for $S$. maritimus, $2.7 \mathrm{~m}$ for $S$. maritima and $2.3 \mathrm{~m}$ for $Z$. noltei. In 2011, the average low tide was $0.9 \mathrm{~m}$, and the average high tide was $3 \mathrm{~m}$. Z. noltei had the highest sedimentation rate for a one-year period $\left(2.7 \mathrm{~cm} \mathrm{y}^{-1} \pm 0.2\right)$, followed by $S$. maritima with $1 \mathrm{~cm} \mathrm{y}^{-1} \pm 0.1$ and $S$. maritimus with the lowest sedimentation rate $\left(0.2 \mathrm{~cm} \mathrm{y}^{-1} \pm\right.$ 0.04). Along western European coasts, the sea level has been increasing at least since the Roman Period, and this increase has accelerated during the Modern Period (Pye, 1995). Salt marshes can keep pace with the sea level increase, but this ability depends on the sedimentation rate (Reed et al., 1990; Pont et al., 2002). In this case, $S$. maritimus could be at risk in the Mondego estuary. Fig. 4 shows that in approximately 37 years, if the sedimentation rates and rates of sea level increase remain the same (which is unlikely), the Z. noltei area would not be immersed during a high tide. As a result, this species would, most likely, disappear from this area. The S. maritima 
sedimentation rate $\left(1 \mathrm{~cm} \mathrm{y}^{-1}\right)$ and sea level $\left(0.9 \mathrm{~cm} \mathrm{y}^{-1}\right)$ are increasing to a similar extent, and the $S$. maritima area should not be greatly influenced by the increasing sea level during the next 50 years. Unlike Z. noltei, S. maritimus could be completely covered during every high tide in approximately 40 years. Of the three study species, $S$. maritimus should show the greatest effects of the sea level increase because its sedimentation rate $\left(0.2 \mathrm{~cm} \mathrm{y}^{-1}\right)$ is lower than the expected rate of increase of sea level. Before the $S$. maritimus area becomes completely submerged, this species will, most likely, be influenced by the salinity increase that accompanies an increase in sea level. Lillebø et al. (2003), working with $S$. maritimus in the same area, showed that salinity affects the dynamics of $S$. maritimus. In fact, the findings of previous studies have indicated that lower biomass values are associated with high salinity, showing that the survival of this species could be threatened by high salinity. Couto et al. (2013) showed that $S$. maritimus accumulated approximately 21 tons of carbon in the tissues in 21 months, compared with 1.9 tons of carbon accumulated in the tissues by $S$. maritima and 0.9 ton by $Z$. noltei. If the species that accumulates the highest amount of carbon of the three species disappears, the carbon sequestration ability of the Mondego estuary may decrease. Silliman et al., 2009 suggest that as much as $90 \%$ of tidal marshland worldwide could be in jeopardy by 2100 because of the increase in sea level.

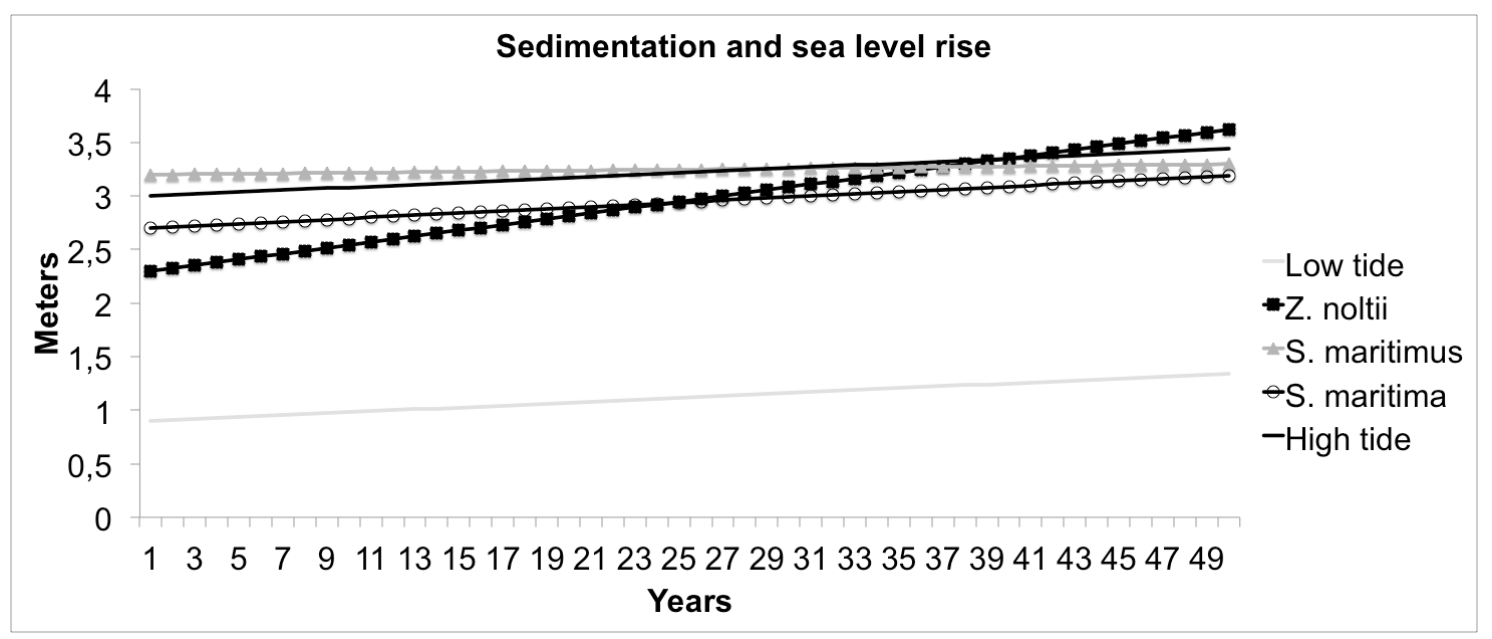

Figure 4. Predicted sea-level rise and sedimentation of the three studied species through 50 years

\section{Conclusions}

The fit of the models for the $\mathrm{C}_{3}$ and $\mathrm{C}_{4}$ plants to the observed biomass values was highly satisfactory. The assumption of a temperature higher than the actual temperature yielded simulated plant biomass values higher than the actual values. This result indicates that the biomass of both $\mathrm{C}_{4}$ and $\mathrm{C}_{3}$ plants would increase and that as a result, carbon sequestration would also increase. The increase in sea level should be prejudicial to salt marsh species. The $S$. maritima sedimentation rate can apparently keep pace with the sea level increase, and $Z$. noltei shows a high sedimentation rate. In contrast, because the $S$. maritimus sedimentation rate is very low, this species could disappear from the Mondego estuary. This scenario would have important implications for the system's carbon sequestration ability because, of the three species examined, $S$. maritimus accumulates the highest quantity of carbon. 
Acknowledgements. The authors would like to thank to the "Fundação para a Ciência e Tecnologia (FCT)" for funding the research in the Centre of Oceanography throughout the project PEstOE/MAR/UI0199/2011 and in the Institute of Marine research (IMAR) throughout the project PEstC/MAR/UI0284/2011. T. Couto investigation was supported by FCT throughout a PhD grant (SFRH / BD / 64608 / 2009). I. Martins was supported by Ciência 2007, QREN, Programa COMPETE (FCT).

\section{REFERENCES}

[1] Anastácio, P.M., Nielsen, S.N., Marques, J.C., Jørgensen, S.E. (1995): Integrated production of crayfish and rice: a management model. - Ecological Engineering 4: 199210.

[2] Bach, H.K. (1993): A dynamic model describing the seasonal variations in growth and the distribution of ellgrass (Zostera marina L.). I. Model Theory. - Ecological Modelling. 65: 31-50.

[3] Baretta-Bekker, J.G., Baretta, J.W., Ebenhoh, W. (1997): Microbial dynamics in the marine ecosystem model ERSEM II with decoupled carbon assimilation and nutrient uptake. - Journal of Sea Research 38: 195-211.

[4] Bluemle, J.P., Sabel, J.M., Karlén, W. (1999): Rate and magnitude of past global climate changes. - Environmental Geosciences 6: 63-75.

[5] Brevik, E.C. and Houmburg, J.A. (2004): A 5000 year record of carbon sequestration from a coastal lagoon and wetland complex, Southern California, USA. - Catena 57: 221232.

[6] Bridgham, S.D., Megonigal, J.P., Keller, J.K., Bliss, N.B., Trettin, C. (2006): The carbon balance of North American wetlands. - Wetlands 26: 889-916.

[7] Caçador, I., Caetano, M., Duarte, B., Vale, C. (2009): Stock and losses of trace metals from salt marsh plants. - Marine Environmental Research 67: 75-82.

[8] Caçador, I., Costa, A., Vale, C. (2004): Carbon storage in Tagus saltmarsh sediments. Water, Air, and Soil Pollution 4: 701-714.

[9] Clarke, K.R. (1993): Non-parametric multivariate analyses of changes in community structure. - Australian Journal of Ecology 18: 117-143.

[10] Couto, T.C., Duarte, B., Caçador, I., Baeta, A., Marques, J.C. (2013): Salt marsh plants carbon storage in a temperate Atlantic estuary illustrated by a stable isotopic analysis based approach. - Ecological Indicators 32: 305-311.

[11] Cundy, A.B. and Croudace, I.W. (1996): Sediment accretion and recent sea-level rise in the Solent, southern England: Inferences from radiometric and geochemical studies. Estuarine, Coastal and Shelf Science 43: 449-467.

[12] Curtis, P.S., Drake, B.G., Whigham, D.F. (1989a): Nitrogen and Carbon Dynamics in C3 and C4 Estuarine Marsh Plants Grown under Elevated CO2 in Situ. - Oecologia 78: 297301.

[13] Curtis, P.S., Drake, B.G., Leadley, P.W., Arp, W.J., Whigham, D.F. (1989b): Growth and Senescence in Plant Communities Exposed to Elevated CO2 Concentrations on an Estuarine Marsh. - Oecologia 78: 20-26.

[14] Duarte, P.M.S. (2011): Manual de Modelação Ecológica - Fernando Pessoa University Press, Porto, Portugal.

[15] Duarte, B., Couto, T., Marques, J.C., Caçador, I. (2012): Scirpus maritimus leaf pigment profile and photochemistry during senescence: implications on carbon sequestration. Plant Physiology and Biochemistry 56, 238-244.

[16] Fragoso Jr., C.R., Ferreira, T.F., Marques, D.M. (2009): Modelagem Ecológica em ecossistemas aquáticos. - Oficina de Textos, São Paulo, Brasil.

[17] Friedrichs, C.T., Perry, J.E. (2001): Tidal salt marsh morphodynamics: a synthesis. Journal of Coastal Research 27: 7-37. 
[18] Giurgevich, J.R., Dunn, E.L. (1981): A comparative analysis of the CO2 and water vapor responses of two Spartina species from Georgia coastal marshes. - Estuarine, Coastal and Shelf Science 12: 561-568.

[19] Gross, M., Hardisky, M., Wolf, P., Klemas, V. (1991): Relationship between aboveground and belowground biomass of Spartina alterniflora (smooth cordgrass). Estuaries 14: 180-191.

[20] Houghton, J. (1999): Global Warming: The Complete Briefing, fourth ed. - Cambridge University Press, New York.

[21] Intergovernmental Panel on Climate Change (IPCC) (2007): Climate change 2007: the physical science basis. - Cambridge University Press, New York.

[22] Jørgensen, S.E. \& Fath, B.D. (2011): Fundamentals of Ecological Modelling, fourth ed. Elsevier, USA.

[23] Kenov, I.A., Garcia, A.C., Neves, R. (2012): Residence time of water in the Mondego estuary (Portugal). - Estuarine, Coastal and Shelf Science 106: 13-22.

[24] Lefeuvre, J.C., Laffaille, P., Feunteun, E., Bouchard, V., Radureau, A. (2003): Biodiversity in salt marshes: from patrimonial value to ecosystem functioning. The case study of the Mont-Saint-Michel bay. - Comptes Rendus Biologies 326: 125-131.

[25] Lillebø, A.I., Pardal, M.A., Neto, J.M., Marques, J.C. (2003): Salinity as the major factor affecting Scirpus maritimus annual dynamics Evidence from field data and greenhouse experiment. - Aquatic Botany 77: 111-120.

[26] Magenheimer, J.F., Moore, T.R., Chmura, G.L., Daoust, R.J. (1996): Methane and carbon dioxide flux from a macrtotidal salt marsh, Bay of Fundy, New Brunswick. - Estuaries 19: 139-145.

[27] Marques, J.C., Nielsen, S.N., Pardal, M.A., Jørgensen, S.E. (2003): Impact of eutrophication and river management within a framework of ecosystem theories. Ecological Modelling 166: 147-168.

[28] Marques, J.C., Maranhão, P., Pardal, M.A. (1993): Human impact assessment on the subtidal macrobenthic community structure in the Mondego estuary (Western Portugal). Estuarine, Coastal and Shelf Science 37: 403-419.

[29] Marques, J.C., Nogueira, A. (1991): Life cycle, population dynamics, and production of Echinogammarus marinus (Leach) (Amphipoda) in the Mondego estuary (Portugal). Acta Oecologica 11: 213-223.

[30] Morris, J.T. (1982): A model of growth responses by Spartina alterniflora to nitrogen limitation. - Journal of Ecology 70: 25-42.

[31] Mudd, S.M., Howell, S.M., Morris, J.T. (2009): Impact of dynamic feedbacks between sedimentation, sea-level rise, and biomass production on near-surface marsh stratigraphy and carbon accumulation. - Estuarine, Coastal and Shelf Science 82: 377-389.

[32] Neto, J.M., Flindt, M.R., Marques, J.C., Pardal, M.A. (2008): Modelling nutrient mass balance in a temperate meso-tidal estuary: implications for management. - Estuarine, Coastal and Shelf Science 76: 175-185.

[33] Pont, D., Day Jr, J.W., Hensel, P., Franquet, E., Torre, F., Rioual, P., Ibàñez, C. \& Coulet, E. (2002): Response scenarios for the deltaic plain of the Rhône in the face of an acceleration in the rate of sea-level rise with special attention to Salicornia-type environments. - Estuaries. 25: 337-358.

[34] Pye, K. (1995): Controls on long-term saltmarsh accretion and erosion in the Wash, Eastern England. - Journal of Coastal Research 11: 337-356.

[35] Reed, D.J. (1990): The impact of sea-level rise on coastal salt marshes. - Progress in Physical Geography 14: 465-481.

[36] Rybczyc, J.M. \& Cahoon, D.R. (2002): Estimating the potential for submergence for two wetlands in the Mississippi river delta. - Estuaries. 25: 985-998.

[37] Simas, T.C. and Ferreira, J.G. (2007): Nutrient enrichment and the role of salt marshes in the Tagus estuary (Portugal). - Estuarine, Coastal and Shelf Science 75: 393-407. 
[38] Simas, T., Nunes, J.P., Ferreira, J.G. (2001): Effects of global climate change on coastal salt marshes. Ecological Modelling - 139: 1-15.

[39] Silliman, B.R., Grosholz E.D., Bertness, M.D. (2009): Human impacts on salt marshes: A global perspective. - University of California Press, USA.

[40] Sousa, A.I., Lillebø, A.I., Pardal, M.A., Caçador, I. (2010): The influence of Spartina maritima on carbon retention capacity in salt marshes from warm-temperate estuaries. Marine Pollution Bulletin 61: 215-223.

[41] Teixeira, H., Salas, F., Borja, Á., Neto, J.M., Marques, J.C. (2008): A benthic perspective in assessing the ecological status of estuaries: The case of the Mondego estuary (Portugal). - Ecological Indicators 8: 404-416.

[42] Titus, J.G. (1991): Greenhouse effect and coastal wetland policy: how Americans could abandon an area the size of Massachusetts at minimum cost. - Environmental Management 15: 39-58.

[43] Vandenbruwaene, W., Maris, T., Cox, T.J.S., Cahoon, D.R., Meire, P., Temmerman, S. (2011): Sedimentation and response to sea-level rise of a restored marsh with reduced tidal exchange: Comparison with a natural tidal marsh. - Geomorphology 130: 115-126.

[44] Williams, J.R. (1999): 'Addressing global warming and biodiversity through forest restoration and coastal wetlands creation'. - Science of the Total Environment 240: 1-9. 